s. Adelajda Sielepin CHR

\title{
Treści teologiczne w odnowionej księdze Obrzędy konsekracji dziewic
}

„Konsekracja dziewic należy do najcenniejszych skarbów liturgii rzymskiej”. Tak rozpoczyna się dekret Kongregacji Kultu Bożego promulgujący odnowione Obrzędy konsekracji dziewic ${ }^{1}$. To bezcenne znaczenie konsekracji bierze się z tego, że dziewictwo poświęcone Bogu jest, jak mówi dalej dokument, „wzniosłym darem, jaki zostawił Jezus Chrystus swojej Oblubienicy w dziedzictwie"2. Od najdawniejszych czasów dziewice poświęcały swoją czystość Bogu (por. Dz 21, 8-9), a Kościół doceniał i zatwierdzał to oddanie specjalnym błogosławieństwem oraz aktem konsekracji³. Odnowiona niedawno księga Obrzędów konsekracji dziewic skłania nas do wnikliwszego spojrzenia na teologię tego czcigodnego aktu i powołania w Kościele.

\section{Przeszłość}

Najstarszą formą konsekracji była uroczysta modlitwa konsekracyjna, która z czasem została ubogacona i w ten sposób powstał specjalny ryt konsekracji dziewic. Należała ona także do rzymskiego rytuału w Sakramentarzu Gelazjańskim ${ }^{4}$, choć najstarsze dokumenty na ten temat pochodzą

\footnotetext{
${ }^{1}$ Kongregacia Kultu Bożego, Dekret promulgujący odnowione Obrzędy konsekracji dziewic (31 marca 1970), [w:] Pontyfikat Rzymski odnowiony zgodnie z postanowieniem świętego Soboru powszechnego Watykańskiego II wydany z upoważnienia papieża Pawła VI, poprawiony staraniem papieża Jana Pawła II. Obrzędy konsekracji dziewic (OKDz), wydanie wzorcowe, Katowice 2001, s. 7.

${ }^{2}$ Tamże.

${ }^{3}$ Żeńska forma życia konsekrowanego pojawiła się w starożytności w Palestynie, Rzymie, Mediolanie, Arles, Poitiers. Do znanych postaci należały: siostra św. Antoniego, siostra św. Pachomiusza Maria czy siostra św. Benedykta Scholastyka. Św. Augustyn nazywa takie kobiety sanctimoniales (święte mniszki), a później moniales (mniszki), por. S. Augustinus, De sancta virginitate, c. 57, [w:] PL 40, 428. Por. J. HourCADE, L'Ordre des vierges consacrées, „Vie consacrée” 5 (1993), s. 298; P. ANNAERT, Femmes et service d'Eglise dans la tradition historique occidentale, „Vie consacrée” 5 (2003), s. 311-314.

${ }^{4}$ Por. Sacramentarium Gelasianum (GeV I, CIII) z VIII wieku, który w zasadzie reprodukuje wcześniejsze teksty z Sakramentarza Leonińskiego, zawierającego najstarsze teksty liturgiczne. Część z nich znalazła się następnie w późniejszym Sakramentarzu Hadriańskim.
} 
już z IV wieku'. Już wtedy obok modlitwy konsekracyjnej do najistotniejszych elementów obrzędu należało przekazanie welonu, a potem wieńca i pierścienia - obrączki ${ }^{6}$. Konsekracja dziewic dotyczyła początkowo kobiet żyjących jeszcze przy rodzinach i dawała im pewną autonomię wobec uwarunkowań rodzinnych i społecznych. Akt konsekracji określał wyłączną przynależność kobiety do Chrystusa, co wyrażało się w bezpośredniej zależności od biskupa miejsca i tak pozostało do dnia dzisiejszego ${ }^{7}$. Gdy w średnioweczu w Kościele rozkwitło życie wspólnot konsekrowanych także i dla kobiet, obrzęd ten został przez nich podjęty i do dzisiaj dotyczy niektórych wspólnot mniszych, jak też kobiet żyjących w świecie poza klasztorem (od X w.).

Ryt został zatwierdzony w Pontyfikale Rzymskim w 1595 r. po Soborze Trydenckim. Był on sprawowany przed lub po Mszy świętej. W 1927 r. Pius XI wykluczył możliwość stosowania tego obrzędu dla dziewic żyjących w świecie, a w 1950 r. Pius XII wzmocnił to stanowisko, zastrzegając go wyłącznie dla mniszek. Dopiero Konstytucja Sponsa Christi (21 XI 1950) tego samego papieża dopuściła stosowanie tego rytuału w wielu klasztorach, nie tylko mniszych. Konsekracja jest liturgią oblubieńczych zaślubin z Chrystusem, dlatego tak istotnym dla konsekracji jest ślub życia w dziewictwie jako znak przyszłej rzeczywistości, kiedy wszyscy dostąpią udziału w eschatologicznych godach Baranka i Kościoła ${ }^{8}$.

\section{Teraźniejszość}

Aktualne Obrzędy Konsekracji Dziewic (Ordo consecrationis virginum) zostały odnowione zgodnie z postulatem Soboru Watykańskiego II, który zalecił: „Należy ponownie opracować obrzęd konsekracji dziewic, znajdujący się w Pontyfikale Rzymskim. Oprócz tego należy ułożyć obrzęd profesji zakonnej i odnowienia ślubów, aby odznaczały się większą jednolitością, prostotą i dostojeństwem. Powinien on obowiązywać tych, którzy składają profesję wieczystą lub odnawiają śluby podczas Mszy świętej, z zachowaniem jednak prawa partykularnego. Godny pochwały jest zwyczaj składania profesji zakonnej podczas Mszy świętej” (KL 80).

5 „Ad virginis sacras: Respice Dne propitious super has famulas tuas, | ut virginitatis sanctae propositum, | quod te inspirante suscipiunt, | te gubernante, custodiant" (Sacramentarium Leonianum, 139, 20); „Oratio ad ancillas Dei velandas: Famulaas tuas Dne tuae custodia muniat pietatis, | ut virginitatis sanctae propositum, | quod te inspirante susceperunt, | te protegente, inlaesum custodiant" (Sacramentarium Hadrianum, 215).

${ }^{6}$ Por. Lexicon für Theologie und Kirche, t. 5, Fryburg 1960, s. 1213; E. Gambari, Życie zakonne po Soborze Watykańskim II, tłum. J. E. Bielecki, Kraków 1998, s. 70.

${ }^{7}$ Por. Dekret promulgujący odnowione Obrzędy konsekracji dziewic, dz. cyt., s. 7; Wprowadzenie ogólne, 6, [w:] OKDz.

${ }^{8}$ Por. KK 44, 48, DZ 12. 
Zajęła się tym Rada do wykonania Konstytucji o liturgii. Zmodyfikowane obrzędy zostały zatwierdzone przez Pawła VI i promulgowane 31 maja 1970 r. w święto Nawiedzenia Najświętszej Maryi Panny jako wzorcowe.

Księga ta doczekała się jeszcze korekty dzięki staraniom Jana Pawła II. Tłumaczenie polskie, przyjęte przez Konferencję Episkopatu Polski, zostało zatwierdzone przez Kongregację Kultu Bożego i Dyscypliny Sakramentów dekretem z dnia 28 maja 1990 r. W Polsce odnowione obrzędy zostały oficjalnie zalecone dekretem Prymasa Polski z dnia 8 VI 1999, a wydane przez wydawnictwo św. Jacka w Katowicach w 2001 r. Dotyczą one zarówno mniszek, jak i dziewic żyjących w świecie. Księga składa się z następujących części:

Odpowiednie dekrety,

Wprowadzenie ogólne,

I. Konsekracja dziewic,

II. Konsekracja dziewic połączona z profesją mniszek,

III. Teskty do wyboru przy konsekracji dziewic, tzn. czytania biblijne i śpiewy, formy obrzędowe i antyfony do wyboru,

Dodatek: wzór formuły profesji.

\section{Struktura dialogowa a Misterium}

Obrzęd konsekracji połączony z profesją zbudowany jest na zasadzie podobnej do innych sakramentów o charakterze konsekracyjnym, takich jak: chrzest, bierzmowanie czy kapłaństwo. Oto jego poszczególne części:

Wezwanie dziewic,

Homilia lub przemówienie przedstawiające wartość dziewictwa,

Pytania (dialog) dotyczące pragnienia i przyjęcia konsekracji,

Litania,

Odnowienie lub złożenie profesji,

Uroczysta konsekracja dziewic,

Przekazanie znaków konsekracji.

Charakterystyczną cechą jest forma dialogu, która czytelnie ukazuje istotę misterium konsekracji, a jest nią rzeczywistość zaślubin Chrystusa z Kościołem, a w nim z poszczególnym człowiekiem. W związku z tym konsekracja czyni ochrzczonego znakiem eschatologicznym, obrazem miłości Kościoła do Chrystusa, pozwalając mu już teraz na antycypację przyszłego życia ${ }^{9}$. Konsekracja dziewic jest dojrzałym podjęciem pierwszej konsekracji, dokonanej na chrzcie. Wyraża się ona w tym wypadku bardziej od strony człowieka, potwierdzając tę pierwszą.

\footnotetext{
${ }^{9}$ Por. OKDz 1.
} 
Dialog, któremu przewodniczy biskup, ma na celu uświadomienie Kościołowi personalnej relacji między Bogiem a człowiekiem, jak też otrzymanego daru $^{10}$, czyli powołania, na które wezwany odpowiada: „Oto jestem, Panie”11. Przyjęcie daru i udzielenie odpowiedzi na ten dar ma się weryfikować w życiu przez wypełnienie Bożej misji zadanej w powołaniu ${ }^{12}$. W dialogu, a zwłaszcza w pytaniach, Kościół daje nam do zrozumienia, że Bóg oczekuje na świadomą i dobrowolną decyzję człowieka, uczynioną z miłości, ożywianej wciąż paschalną miłością Chrystusa. Ma się ona stać gwarancją trwałości przymierza z Chrystusem, w ramach którego prowadzony jest nieustanny i twórczy dialog Oblubieńca z Oblubienicą ${ }^{13}$. Dzięki liturgii dialog ten polega na niezwykłej wymianie miłości (uświęcenie i kult) między osobami Misterium (dramatis personae to Chrystus i Kościół), a sama konsekracja jako sakramentale staje się dodatkowym środkiem uświęcenia człowieka ${ }^{14}$, jak też pozwala osobie konsekrowanej w szczególnie eschatologiczny, choć widzialny sposób, uczestniczyć w nowym kulcie Kościoła. Kontekst Mszy świętej, zalecany dla aktu konsekracji ${ }^{15}$, wyraża, że misterium miłości, jakie jest ukazane w konsekracji lub w profesji, czerpie zawsze z jednego źródła Miłości, jakim jest Chrystus obecny w Eucharystii.

\section{Rozwinięcie konsekracji chrzcielnej}

Punkt kulminacyjny obrzędów konsekracji, jakim jest modlitwa konsekracyjna, wyrasta z przygotowania, które sięga chrzcielnej i pierwszej konsekracji. Nawiązuje do tego dialog wstępny i zapalone świece. Słowa rozpoczynające dialog nawiązują do tego pierwotnego aktu inaugurującego przynależność do Chrystusa: „Drogie siostry, już przez chrzest umarłyście dla grzechu i zostałyście poświęcone Bogu. Pytam każdą z was: Czy chcesz przez wieczystą profesję ściślej zjednoczyć się z Bogiem?"16

Kiedy dziewice, mające przyjąć konsekrację, wchodzą procesjonalnie z zapalonymi świecami do prezbiterium, śpiewa się antyfonę: „Roztropne dziewice, przygotujcie swoje lampy. Oblubieniec wasz nadchodzi, wyjdźcie Mu na spotkanie."17

${ }^{10}$ Por. JAN Pawet II, adhort. ap. Vita consecrata, Watykan 1996, 1.

${ }^{11}$ Por. OKDz 15.

${ }^{12}$ Por. W. Świerzawski, Kapłaństwo, Wrocław 1984, s. 272.

${ }^{13}$ Por. na ten temat: tamże, s. 245-257, 268-281; A. HoAng, La dimension sponsale de l'Alliance signifiée dans la vie consacrée, „Vie consacrée” 5 (2003), s. 292-306.

${ }^{14}$ Por. KL 60-61.

${ }^{15}$ Por. OKDz 5.

${ }^{16} \mathrm{OKDz} 55$.

${ }^{17} \mathrm{OKDz} 13,51$. 
Formuła ta pochodzi z dawnego jeszcze obrzędu: Prudentes virgines, aptate lampades vestras ${ }^{18}$. Zapalone światło należy do symboliki chrzcielnej. Ojcowie Kościoła (św. Grzegorz z Nazjanzu) często odnosili symbol zapalonego światła do chrzcielnej mądrości i roztropności w czujnym oczekiwaniu na Oblubieńca. Zachęcali, by neofici strzegli tego światła przez całe życie, bo „nikt nie zna dnia ani godziny, kiedy Syn Człowieczy ma przyjść” (por. Mt $24,42)^{19}$. Konsekracja jest zatem kontynuacją i podjęciem na nowo i w nowy sposób konsekracji chrzcielnejej ${ }^{20}$ Jest świadomą odpowiedzią na Boże powołanie, czego potwierdzeniem jest aklamacja wypowiadana na początku: „Oto jestem, Panie, bo mnie wezwałeś" (1 Sm 3, 6).

\section{Oblubieńcza i płodna miłość}

Modlitwa konsekracyjna zawiera w sobie całą istotę obrzędu i w liturgiczny sposób powierza człowieka Chrystusowi na wyłączną własność. Ten akt wraz z przekazaniem welonu należy do najstarszych w tradycji Kościoła. Modlitwa ta podejmuje kilka wątków, z czego najważniejszym jest oblubieńczy akt przynależności do Chrystusa. Na wstępie modlitwa ukazuje wartość czystości jako wyjątkowego daru Bożego, który służy pełniejszemu oddaniu się Chrystusowi i w którym Bóg ma szczególne upodobanie: „Boże, Ty mieszkasz w czystych ciałach i kochasz dusze nieskalane"21.

Kościół od początku szanował ten dar, uznając dziewice konsekrowane za „ozdobę Mistycznego Ciała Chrystusa, obdarzające je przedziwną płodnością" ${ }^{22}$. Następnie modlitwa podkreśla, że dar ten udzielany wybranym ochrzczonym - „dzieciom zrodzonym nie z krwi ani z woli ciała, ale z Ducha Świętego"23 - czyni ich znakiem eschatologicznym i pozwala im, prowadzącym jeszcze życie doczesne, „,doświadczyć niektórych radości, jakie na nich czekają w życiu przyszłym”24. Modlitwa wyraźnie mówi, że konsekracja jest rzeczywistością, jaką znak małżeństwa tylko zapowiada ${ }^{25}$, i jest „,znakiem przyszłego królestwa”26, którego „małżeństwo jest cieniem”27. Z tego wynika jasno, że ani

${ }^{18}$ Ordo consecrationis virginum, editio typica, Libreria Editrice Vaticana 1978, 13. 51.

${ }^{19}$ Por. S. Gregorius Nazianzenus, Oratio 40: In Sanctum baptisma, 46, [w:] PG 36, 426.

${ }^{20}$ Por. F. Marlot, Consécration, „Vie consacrée” 4 (1993), s. 220-222.

${ }^{21}$ Uroczysta modlitwa konsekracyjna, [w:] OKDz 24.

${ }^{22}$ Dekret promulgujący odnowione Obrzędy konsekracji dziewic, [w:] OKDz.

${ }^{23}$ Uroczysta modlitwa konsekracyjna, [w:] OKDz 24.

${ }^{24}$ Tamże.

${ }^{25}$ Por. tamże: „nie zawierają małżeństwa, ale miłują rzeczywistość, którą ten znak zapowiada".

${ }^{26}$ Por. OKDz 17.

27 „Niektóre z nich z Twego natchnienia wyrzekają się ludzkiego związku, a pragną związku wyższego, którego małżeństwo jest cieniem” (Modlitwa konsekracyjna, OKDz 24). 
konsekracja, ani profesja zakonna nie są sakramentami, ponieważ stanowią samą rzeczywistość Misterium Chrystusa i Kościoła (por. Ef 5, 32). W modlitwie konsekracyjnej, która jest podstawowym liturgicznym aktem oddania się Chrystusowi, znajdujemy też prośbę o łaskę dla obrony czystości i dla owocowania tej cnoty w duchowej płodności dla rozwoju Królestwa Boga. „Niech w Chrystusie znajdą wszystko, bo ponad wszystko Go wybrały"28. W homilii obrzędowej biskup odsłania przed kandydatkami do konsekracji wzniosłość ich powołania i wybrania, na którego owoce Kościół liczy, chcąc pomnażać duchowe owoce swojego macierzyństwa. W tym sensie uważa dziewice konsekrowane za swoje jedyne reprezentantki, które zostały powołane po to, by wydać i pielęgnować owoce zbawczej płodności: „Święta Matka Kościół uważa was za wybraną cząstkę ludu Bożego, bo przez was rozkwita jego duchowa płodność”29.

Potwierdzeniem zewnętrznym konsekracji jest liturgiczne przekazanie znaków konsekracji, czyli welonu i obrączki ${ }^{30}$. Towarzyszy temu śpiew odpowiedniego psalmu lub hymnu ${ }^{31}$. Według dawnego obrzędu z Pontyfikału Trydenckiego mniszki konsekrowane miały odpowiadać na widok obrączki w następujących słowach: zaślubiam Tego, „quem vidi, quem amavi, in quem credidi, quem dilexi. Słowa te, zaczerpnięte ze słów św. Agnieszki, które wypowiedziała przed śmiercią, wyznając wiarę w Chrystusa, odsłaniają dynamikę relacji oblubienicy do Oblubieńca: vidi (zmysły), amavi (miłość ludzka, uczucie), credidi (wiara) i wreszcie dopiero dilexi-dilectio, czyli miłość Boska, agape, otrzymana darmo w liturgii, zwłaszcza w Eucharystii.

\section{Wątek Maryjny}

Chociaż konsekracja jest zawsze rozumiana analogicznie do jedynej i wyjątkowej konsekracji Matki Jezusowej, to obrzędy liturgiczne konsekracji są dosyć skąpe w teksty bezpośrednio mówiące o Maryi. Zasadniczo znajdujemy tylko dwie wzmianki o Matce Bożej, obie odnoszące się do tajemnicy Wcielenia.

Pierwszy z nich pojawia się w końcowym obrzędzie błogosławieństwa i odesłania konsekrowanych dziewic: „Duch Święty, który zstąpił na Najświętszą Dziewicę i dzisiaj uświęcił wasze serca swoim dotknięciem, niech zapali was do gorliwej służby Bogu i Kościołowi”32.

Słowa te brzmią jak przekazanie konsekrowanym w sposób uroczysty najważniejszej misji w Kościele, jaką jest świadome życie dla spraw Pana (por.

\footnotetext{
${ }^{28}$ Tamże.

${ }^{29}$ Homilia obrzędowa, [w:] OKDz 16.

${ }^{30}$ Por. OKDz 25-28; 65-67.

${ }^{31}$ Por. Ps 45, [w:] ODKDz 27, 68.

${ }^{32} \mathrm{OKDz} 36,77$.
} 
1 Kor 7, 34), czyli spalanie się w budowaniu Królestwa Bożego i oddanie swoich sił w całopalnej ofierze Bogu i ludziom. Wszystko ma się dokonywać analogicznie do Maryi. Ona za sprawą Ducha Świętego całkowicie otworzyła się na Chrystusa i odtąd On i Jego dzieło zbawcze wraz z ludźmi, dla których przyszedł, stały się Jej wszystkim do tego stopnia, że Syn uczynił Ją Matką także i Kościoła. Łaska konsekracji polega na tym, że ten sam Duch, co w Maryi, przyczynia się do wzrostu duchowej „pojemności” osoby konse-

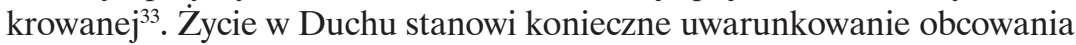
z Bogiem. Konsekracja zapewnia takie warunki ze względu na uświęcającą ingerencję Ducha Parakleta i ułatwienie przez Maryję doświadczenia własnej całkowitości, by otworzyć swoje duchowe receptory na przychodzącego Pana, któremu trzeba oddać się do końca.

Drugi tekst, w którym spotykamy akcent Maryjny, występuje w proponowanej przez obrzęd homiliii ${ }^{34}$ związany jest z tajemnicą Wcielenia, która jest kluczową tajemnicą odsłaniającą przed nami znaczenie dziewictwa. Bez niego Maryja nie mogłaby w pełni partycypować w życiu Boga: „Gdy nadeszła pełnia czasów, wszechmogący Ojciec w misterium Wcielenia ukazał, jak miłuje dziewictwo. Wybrał bowiem Dziewicę, w której najczystszym łonie za sprawą Ducha Świętego Słowo stało się ciałem i natura ludzka połączyła się oblubieńczym związkiem z naturą boską"35.

Tekst ten ukazuje niepowtarzalny już u nikogo w ten sposób styk relacji oblubieńczej i macierzyńskiej. Maryja stała się dzięki ingerencji Ducha Świętego i wyjątkowej, danej przez Boga otwartości, Matką Mesjasza pozostając jednocześnie Dziewicą. To wydarzenie zaślubin Boskiej natury z ludzką w Maryi staje się wzorem każdej innej relacji oblubieńczej w jej wymiarze nadprzyrodzonym: najpierw relacji między Chrystusem a Kościołem, następnie relacji między Chrystusem a człowiekiem poprzez konsekrację, a wreszcie relacji między mężczyzną a kobietą, którzy przez sakramentalny znak małżeństwa mają być odbiciem miłości oblubieńczej Chrystusa i Kościoła.

To jedyne i niepowtarzalne powołanie Maryi zostało określone jako macierzyństwo o „charakterze oblubieńczym” (M. J. Scheeben) i jest przedmiotem refleksji w obrzędzie konsekracji, która nadaje konsekrowanym ten właśnie rys Maryjny. Ich oblubieńcza miłość z Chrystusem staje się analogicznie do Maryi, tylko że jedynie w sferze ducha, źródłem duchowej płodności. Maryja jawi się w tym przypadku jak wzór doskonałej konsekracji, polegającej na idealnej całkowitości. Zarówno powołanie Maryi, jak

\footnotetext{
${ }^{33}$ Por. F. MARlot, Consécration, art. cyt., s. 216-217.

${ }^{34}$ Por. Homilia obrzędowa, [w:] OKDz 16.

${ }^{35}$ Tamże.
} 
i powołanie do konsekracji pochodzą z inicjatywy Boga i domagają się od człowieka jedynie właściwej odpowiedzi. Maryja więc przypomina swoim przykładem, że każdy, a więc tym bardziej osoba konsekrowana, winien się liczyć z uprzedzającą łaską Pana i wciąż trwać w postawie dawania pierwszeństwa Chrystusowi.

Jest jeszcze jeden tekst Maryjny, zawarty w modlitwie konsekracyjnej, pozostawiony jednak do wyboru ze względu na trudność interpretacyjną: „Agnovit auctorem suum beata virginitas, | et, aemula integritatis angelicae, | illius thalamo, illius cubiculo se devovit, | qui sic perpetuae virginitatis est Sponsus, | quemadmodum perpetuae virginitatis est Filius"36.

W tłumaczeniach na języki nowożytne odniesienie do Maryi w tym fragmencie w ogóle się nie ujawnia, a w wersji polskiej zupełnie pominięto ten urywek $^{37}$. Nie świadczy to jednak, że tekst ten nie ma ważnej wymowy teologicznej. Mówi on o podobieństwie między Maryją Dziewicą a dziewicami konsekrowanymi. Ks. Konecki posłużył się w swoim artykule cenną egzegezą I. M. Calabuiga ${ }^{38}$, który fragment ten tłumaczy następująco: beata virginitas (dziewica chrześcijańska) rozpoznaje twórcę jej dziewictwa, które jest darem i jej tożsamością jej osoby (agnovit auctorem suum). Rozpoznaje w Chrystusie Twórcę jej samej i z wdzięczności daje wyraz swojej przynależności do Niego (illius thalamo, illius cubiculo se devovit). Dalsze dwa wersety zawierają właściwe porównanie: Chrystus jest na zawsze Oblubieńcem dziewic (qui sic perpetuae virginitatis est Sponsus), tak jak na zawsze jest Synem Dziewicy [Maryi] (quemadmodum perpetuae virginitatis est Filius).

Ta nobilitująca człowieka paralela wnosi także swoje zobowiązania do naśladowania Maryi nie tylko w Jej wyniesieniu, ale tym bardziej w Jej wzorowej pokorze Służebnicy Pańskiej. Tak zresztą biskup nazywa przyjmujące konsekrację, wypowiadając słowa Modlitwy konsekracyjnej: „służebnice” $(\text { famulae })^{39}$, a wcześniej w homilii zachęca je do naśladowania Maryi właśnie w Jej postawie Służebnicy: „Naśladując Matkę Bożą, chcecie być służebnicami Pańskimi i pragniecie, aby was tak nazywano"40.

Wiąże się z tym postawa wielbiąca wobec Oblubieńca-Boga i wstawiennictwa do Niego za lud Boży jako wyraz najważniejszej służby Kościołowi

${ }^{36}$ Uroczysta modlitwa konsekracyjna, [w:] OKDz 24.

${ }^{37}$ Por. K. Konecki, Aspekty Maryjne w „Obrzędach profesji zakonnej” $i$ „Obrzędach konsekracji dziewic”, „Anamnesis” 32 (2003), s. 50.

${ }^{38}$ Por. I. M. Calabuig, R. Barbieri, Consacrazione delle vergini, NDL, 308, cyt. za: K. Konecki, Aspekty..., art. cyt., s. 50.

39 „Wejrzyj, Panie, na te swoje służebnice...” („Respice, Domine, super has famulas tuas...) - OKDz (OCV) 24.

${ }^{40}$ „Vos autem, Dei Matrem imitantes, ancillae Domini et esse et appellari optetis...” - OCV 24. 
w jego drodze do zbawienia. Dlatego też, jeśli przemawiają za tym okoliczności, to do znaków konsekracji dołącza się przekazanie Brewiarza ${ }^{41}$ na znak, że jako osoby konsekrowane mają się włączyć w „nieustanne wielbienie Ojca niebieskiego i prośby o zbawienie całego świata”. Obrzęd też określa ów służebny charakter życia dziewic konsekrowanych. Mianowicie zgodnie ze swym stanem i otrzymanym charyzmatem powinny oddawać się pokucie, dziełom miłosierdzia, apostolstwu i gorliwej modlitwie ${ }^{42}$.

Wymiar Maryjny jest nierozłączny z wymiarem eklezjalnym, i taka jest konsekracja już w swojej formie liturgicznej. Dokonuje się przy zgromadzonej wspólnocie, która jest znakiem Kościoła, dla którego osoba konsekrowana żyje i który symbolizuje w swoim eschatycznym i już widocznym powołaniu. Wybrzmiewa to szczególnie w końcowej formie błogosławieństwa: „Duch Święty, który zstąpił na Najświętszą Dziewicę i dzisiaj uświęcił wasze serca swoim dotknięciem, niech zapali was do gorliwej służby Bogu i Kościołowi”"43.

\section{Lektura biblijna}

$\mathrm{Na}$ zakończenie wypada poświęcić nieco uwagi tekstom biblijnym, wybranym i zaproponowanym do wyboru w liturgii konsekracji. Mamy tu niejako trzy zestawy: pierwsze czytanie, psalmy z ewentualnym drugim czytaniem i Ewangelia.

Pierwsze czytanie przygotowuje uczestników liturgii do zrozumienia teologii konsekracji. Sięga ona odwiecznego zamysłu wybrania, jakim jest powołanie człowieka do przyjaznego przymierza z Bogiem, jak w przypadku Abrama-protoplasty ludu wybranego, do uczestnictwa w objawianiu i realizacji zbawczego planu przez funkcję prorocką lub królewską, aż po osobiste więzi z Jahwe, jak to ukazuje choćby księga Ozeasza czy Pieśń nad pieśniami. Wśród proponowanych tekstów są też takie, które mówią o powołaniu całej wspólnoty, w której Bóg ma swoje upodobanie, bo Bóg jest Panem wszystkich, a nie jednostek, dlatego takim zaszczytnym tytułem „błogosławiony szczep Pana” nazywa prorok lud wybrany przez Jahwe (Iz 61, 9-11). Dalszą i doskonalszą realizacją tego wybrania jest wybranie w Chrystusie, który w swoim zbawczym dziele ukazał znaczenie prawdziwej Boskiej miłości agape, która odtąd ma charakteryzować życie nowego ludu wybranego, Kościoła. Z tej racji mamy czytanie z Dziejów Apostolskich o życiu pierwszych chrześcijan, którzy mieli jedno serce, oraz obraz eschatologiczny pełnej realizacji wybrania (Ap 3, 21).

\footnotetext{
${ }^{41}$ Por. OKDz 28; 68.

${ }^{42}$ Por. OKDz 2, 16; 54-55.

${ }^{43}$ OKDz (OCV) 36.
} 
Drugie czytanie rozwija podjęty wątek, ukazując realia tego swoistego wybrania. Mamy więc propozycje z Listów apostolskich św. Pawła, św. Piotra i św. Jana o nowym życiu dla Boga, o powołaniu w Ciele Mistycznym, następnie o cenie, jaką trzeba zapłacić za dar wybrania, a zatem czytania o ofierze i o mądrości krzyża, a przede wszystkim o szczęściu i bliskości z Tym, który wybiera, z Chrystusem, który już w ziemskim wymiarze pozwala kosztować radości wybrania. Jest tu więc mowa o odwiecznym wybraniu przez Boga (Ef), o wzajemności ze strony człowieka, który uznaje najwyższą wartość w Chrystusie Panu (Flp) i troszczy się o niewidzialnego Oblubieńca jak małżonka o sprawy swego umiłowanego. Są też czytania, które ciągle przypominają o niewidzialnym, a więc trudnym charakterze tego wybrania, które polega na życiu ukrytym z Chrystusem w Bogu i wzajemnym trwaniu w Bogu, a Boga w nas. Ostatecznie jest to powołanie do świętości, czyli upodobnienia się do Boskiego Oblubieńca, który jedyny jest święty.

Psalm responsoryjny wyraża właściwą odpowiedź wybranych do konsekracji, którzy powinni Boga wielbić w dziękczynieniu, chętnie przyjmowac Jego wolę, pragnąć Boga i szukać Go, a przede wszystkim z miłością czuwać i wyjść Mu na spotkanie.

Ewangelie następują po tym przygotowaniu i jasno ukazują kontrast między wybraniem przez Boga a wartościami tego świata. W swojej radykalnej nauce Jezus nie obawia się głosić programu błogosławieństw, tajemnic Królestwa objawionych prostaczkom, czyli ufnym i pokornym, prawdy o zaparciu się siebie i wzięciu krzyża, o bezżenności dla Królestwa Bożego, o dobrowolnym ubóstwie, czyli szokująco odmiennej ekonomii, a także o postawach charakterystycznych dla tych, którzy odkrywszy wybranie, wybrali Jezusa i poszli za Nim. Są to Ewangelie o roztropności, czyli o pannach mądrych, o prawdziwych krewnych Jezusa, o zysku stokrotnym, nieoglądaniu się wstecz, o Marii i Marcie, o obumieraniu ziarna i winnym krzewie.

Wszystkie te teksty, zarówno biblijne, jak i liturgiczne, kreślą duchowy wizerunek osoby konsekrowanej - podobnej do Chrystusa dziewiczego, posłusznego i ubogiego oraz do Jego Matki, Dziewicy pełnej łaski. Konsekracja jawi się nam przede wszystkim jako pełniejsze, ale zapoczątkowane na chrzcie, uczestnictwo w Misterium miłości Chrystusa i Kościoła. Ma ono wymiar ponadczasowy, bo jest znakiem eschatologicznym, ale uwzględnia wszystkie istotne pragnienia i uwarunkowania natury ludzkiej, skoncentrowane w miłości oblubieńczej i płodnej, podnosząc je na poziom nieprzemijający. Optymistycznym i realnym przykładem tak rozumianej konsekracji jest Maryja, która ukazuje, że spełnienie swojego podstawowego powołania człowiek może osiągnąć w Chrystusie, powierzając mu się w wierze i miłości. 


\section{Summary}

Theological issues in the renewed Ordo consrcrationis virginum

The new Ordo consecrationis virginum underlines the very ancient and evangelical motif of consecration, which draws us back to baptismal consecration, opening the way to the eschatological feast of the Lamb, which can be anticipated now by total devotion to Christ. The prayer of consecration and partly the homily convey the main theological idea of sponsal and spiritually furtile love, perfectly exemplified in the person of Holy Mary, Mother of God. 